\title{
Evaluating Bacterial Wilt-resistant Tomato Genotypes Using a Regional Approach
}

\author{
D.O. Chellemi, H.A. Dankers, and S.M. Olson \\ University of Florida, North Florida Research and Education Center, Route 3, Box 4370, Quincy, \\ FL 32351 \\ N.C. Hodge \\ University of Florida, Plant Pathology Department, Gainesville, FL 32611
}

J.W. Scott

University of Florida, Gulf Coast Research and Education Center, Bradenton, FL 34203

Additional index words. Lycopersicon esculentum, Pseudomonas solanacearum, Physalis ixocarpa, resistance, tomatillo

\begin{abstract}
Several procedures for evaluating the resistance of tomato (Lycopersicon esculentum Mill.) to bacterial wilt were used to account for diversity in strains of Pseudomonas solanacearum Smith and to approximate resistance under field conditions. Five strains of $P$. solanacearum from Florida and one from North Carolina were inoculated onto 19 tomato genotypes and one tomatillo (Physalis ixocarpa Brot.) genotype using a stem-puncture technique. Genotypes were also transplanted as seedlings into naturally infested soil. Resistance was evaluated by comparing the response of each genotype to the susceptible cultivars Bonny Best and Sunny. With the stem-puncture technique, the mean incidence of disease ranged from $30 \%$ with the strain from North Carolina to $94 \%$ with a strain from northern Florida. Significant differences in the resistance of genotypes and pathogenicity of strains were observed. However, no interaction between strain and genotype was observed. Using naturally infested soil, the mean incidence of disease was $51 \%$ and significant differences in the resistance of genotypes were also observed. Hawaii 7997, Hawaii 7998, and CRA 66 had the lowest incidence of disease, regardless of inoculation method. The results indicate that assessing pathogen diversity and using a combination of resistance screening techniques can facilitate the evaluation of many genotypes, account for potential regional variability in the pathogen, and differentiate levels of field resistance to tomato bacterial wilt.
\end{abstract}

Bacterial tomato wilt, caused by Pseudomonas solanacearum, is a limiting factor for tomato production in many tropical, subtropical, and warm temperate regions of the world (Hayward, 1991). In Florida, bacterial tomato wilt was first reported in 1897 (Rolfs, 1898) and has caused sporadic losses in the southern region of the state (Sonoda et al., 1979). In the 2000-ha Quincy tomato production area in northern Florida, recent crop losses due to bacterial wilt have been especially severe and in some cases have forced growers to abandon entire fields.

Crop rotation is not a viable control tactic because the bacterium is indigenous to soils of Florida and Georgia (Jaworski and Morton, 1964; Sonoda, 1978) and can persist indefinitely in infested fields. Soil fumigation does not provide acceptable levels of season-long disease control (Enfinger et al., 1979). Developing resistant cultivars is the most logical solution for suppressing bacterial wilt epidemics. Although the emphasis of bacterial wilt research in Florida has been on developing resistant cultivars, a cultivar having resistance to $P$. solanacearum and good horticultural characteristics has been difficult to obtain (Scott et al., 1993; Sonoda et al., 1979).

Several bacterial wilt-tolerant genotypes have been released (Anais, 1986; Henderson and Jenkins, 1972; Jaworski et al., 1987), but the resistance often breaks down outside the specific region in which they were developed (Scott et al., 1993). The inability of resistant genotypes to perform consistently in different locations

Received for publication 2 Apr. 1992. Accepted for publication 25 June 1993. Florida Agricultural Experiment Station Journal series R-03038. We thank Susan Lee for technical assistance, Robert Stall for access to his collection of $P$. solanacearum strains, and the Gadsden County Tomato Growers Association for financial assistance. The cost of publishing this paper was defrayed in part by the payment of page charges. Under postal regulations, this paper therefore must be hereby marked advertisement solely to indicate this fact. has been attributed to environmental influences such as temperature (Krausz and Thurston, 1975; Mew and Ho, 1977; Sonoda, 1978) and variability among $P$. solanacearum strains (McLaughlin and Sequeira, 1989; Prior et al., 1990). One way to overcome this problem is to develop a screening process that accounts for the various factors affecting resistance.

The purpose of this study was to evaluate the potential for reducing the incidence of tomato bacterial wilt in the Quincy tomato production area using resistant genotypes. Regional diversity in the pathogen was assessed and several screening techniques were used to account for the potential variability of local $P$. solanacearum strains, minimize variation in results due to fluctuating environmental conditions, and to approximate infections under natural field conditions.

\section{Materials and Methods}

Experiments were conducted in a temperature-controlled greenhouse, with days at 32 to $37 \mathrm{C}$ and nights at 16 to $21 \mathrm{C}$, to minimize variation in resistance expression due to temperature.

Genotypes. Nineteen tomato genotypes (Table 1) and one tomatillo genotype (Lot 8-33487; Rogers NK Seed Co., Naples, Fla.) were selected based on previous reports (published and unpublished) of bacterial wilt resistance. To reduce variability among replications, reactions of the selected genotypes were compared to those of the susceptible tomato cultivars Bonny Best and Sunny in each replication.

Characterization of $P$. solanacearum strains. Strains of $P$. solanacearum were isolated from tomato plants with symptoms of bacterial wilt from various locations in the Quincy production region. Strains were purified and stored in sterile tap water at room temperature between experiments. The ability of strains to oxidize various disaccharides and hexose alcohols was examined to deter- 
Table 1. Bacterial wilt-resistant tomato genotypes used in screening tests.

\begin{tabular}{lll}
\hline \hline Genotype & \multicolumn{1}{c}{ Location or institution ${ }^{2}$} & \multicolumn{1}{c}{ Source of resistance } \\
\hline Capitan & Petoseed Co. & CRA 66 \\
Caraibo & INRA, West Indies & CRA 66 \\
CL 5915-93 & AVRDC, Taiwan & $?$ \\
CL 5915-153 & AVRDC, Taiwan & $?$ \\
CRA 66 & INRA, West Indies & West Indies ecotype \\
FMX 192 & Ferry Morse Seed Co. & $?$ \\
GA 219 & Univ. of Georgia & PI 126408 (Lycopersicon esculentum) \\
GA 1095 & Univ. of Georgia & PI 196298 (L. esculentum) \\
GA 1405 & Univ. of Georgia & PI 251323 (L. pimpinellifolium) \\
GA 1565 & Univ. of Georgia & PI 263722 (L. esculentum) \\
Hawaii 7997 & Univ. of Hawaii & PI 127805A (L. pimpinellifolium) \\
Hawaii 7998 & Univ. of Hawaii & PI 127805A (L. pimpinellifolium) \\
Island Red & Yates Brothers, Trinidad & $?$ \\
IHR 66 & ICAR, India & $?$ \\
PI 126408 & Univ. of Florida & L. esculentum \\
Tomatillo & Rogers NK Seed Co. & Physalis ixocarpa \\
Venus & North Carolina State Univ. & PI 129080 (L. esculentum var cerasiforme) \\
XPH 5675 & and Beltsville 3841 (L.esculentum) & \\
XPH 5677 & Asgrow Seed Co. & $?$ \\
84 BWR & Asgrow Seed Co. & $?$ \\
${ }^{2 L o c a t i o n ~ o r ~ i n s t i t u t i o n ~ w h e r e ~ r e s i s t a n c e ~ s c r e e n i n g ~ w a s ~ p e r f o r m e d . ~ I N R A ~=~ I n s t i t u t e ~ N a t i o n a l ~ d e ~ l a ~ R e c h e r c h e ~ A g r o n o m i q u e ; ~}$ \\
AVRDC = Asian Vegetable Research and Development Center; ICAR = International Center for Agricultural Research.
\end{tabular}

mine biovar grouping (Hayward, 1964). Race designation was determined by inoculating seedlings of 'Hicks' tobacco (Nicotiana tabacum), 'Bonny Best' tomato, 'Golden Summer' pepper (Capsicum annuum), and 'Mini Finger' eggplant (Solanum melongena) (Buddenhagen et al., 1962). Five strains from the Quincy production area and a sixth strain (K60) isolated from tomato in North Carolina (Kelman and Person, 1961) were used in inoculations. Seedlings were inoculated by the stem-puncture technique described below and observed for developing bacterial wilt symptoms for 3 weeks.

A quantitative measure of diversity among strains isolated from Quincy was obtained by comparing their fatty acid profiles to profiles of $20 P$. solanacearum strains collected from various plant hosts and locations around the world (from R.E. Stall, Univ. of Florida, Gainesville). The collection of strains contained members from races 1,2 , and 3 and biovars 1,2 , and 3 .

Strains were grown on trypticase soy broth agar for $24 \pm 2 \mathrm{~h}$ at $28 \pm 1 \mathrm{C}$. Cellular fatty acids were derivatized to fatty acid methyl esters (FAMEs) (Miller, 1982). Statistical analyses of FAME profile data were conducted using the MIDI Microbial Identification System, Newark, Del. version 3.60 (Sasser, 1990a). Cluster analysis of the FAME profiles was performed with the MIDI dendrogram software program. Strains within a Euclidian distance (ED) of 10 were considered to be the same species, while strains that link within six units were considered to be the same subspecies or biotype (Sasser, 1990b).

Stem-puncture inoculation technique. Seeds were sown in Metro-Mix 220 (W.W. Grace, Cambridge, Mass) in polystyrene planter flats containing 72 individual cells, each with a volume of $65.5 \mathrm{~cm}^{3}$. Seedlings were thinned to one per cell. Four-week-old seedlings were inoculated using the stem-puncture technique (Winsted and Kelman, 1952), which consists of forcing a sharp needle into the stem through a drop of bacterial suspension that has been placed in the axil of the second or third expanded leaf below the stem apex.

Inoculum was prepared from 2-day-old colonies growing on nutrient agar with yeast extract at 27C. Bacterial suspensions were diluted in sterile tap water to $5.0 \times 10^{8}$ colony-forming units $(\mathrm{cfu}) /$ $\mathrm{ml}\left(\mathrm{OD}_{600 \mathrm{~nm}}=0.775\right)$. Ten plants per genotype were inoculated. Plants were incubated in the greenhouse and observed for the presence of bacterial wilt symptoms after 18 days. The experiment was replicated three times.

Infested soil technique. Infested soil, a Carnegie loamy fine sand (Plinthic Kandiudult: Clayey, Kaolinitic, Thermic) with a pH of 5.3 and an organic content of $4.0 \%$, was obtained from a tomato farm in Gadsden County, Fla., in Nov. 1991. Soil was collected from the base of plants with symptoms of bacterial wilt, passed through a $1-\mathrm{cm}$ mesh screen to remove plant debris, and stored in plastic containers. The inoculum density of the soil was determined before each replication using a modified soil dilution plating technique (Chellemi et al., 1992).

Four-week-old seedlings were transplanted into $700-\mathrm{cm}^{3}$ pots containing infested soil. Ten pots, each containing one seedling, were prepared for each genotype. After transplanting, the pots were incubated in the greenhouse and observed for the presence of bacterial wilt symptoms for 42 days. At the end of each experiment, the bacterium was isolated from several symptomatic plants to confirm the presence of the pathogen. The experiment was repeated three times.

Data analysis. Disease incidence for each genotype was expressed as a percentage of the incidence on the susceptible control cultivars Sunny and Bonny Best. Data were checked for normality and, when appropriate, transformed using the inverse sign transformation. Data from the stem-puncture inoculations were analyzed as a $6 \times 20$ factorial design with combinations of six strains and 20 genotypes. An analysis of variance was conducted to determine the significance of main effects or interactions using SAS's General Linear Model Procedure (SAS Institute, 1988). Data from the infested soil inoculations were analyzed as a randomized complete-block design, with replications over time as the block. Analysis of variance was conducted to determine if there were significant differences in resistance among genotypes. 


\section{Results}

All strains were characterized as race 1, producing symptoms of bacterial wilt in tomato, pepper, and eggplant. No symptoms were produced on tobacco. All of the strains failed to oxidize the disaccharides and hexose alcohols and were classified as belonging to biovar 1.

A dendrogram of fatty acid profiles linked the 30-member population of strains at <10 ED units (Fig. 1), a result indicating that all of the samples are likely to be the same species (Sasser, 1990b). Six clusters linked at $>6$ ED units, a result indicating that the population may represent several $P$. solanacearum subspecies or biotypes. Strains from the Quincy production area were found in four of the six clusters.

The stem-puncture technique indicated significant differences in strain pathogenicity and genotype resistance (Table2). However, there was no significant strain $\times$ genotype interaction. Strains from the Quincy production area were significantly more virulent than the strain from North Carolina (Table 3). Symptoms developed in at least $60 \%$ of the plants for all genotypes (Table 4). The genotypes Hawaii 7997, Hawaii 7998, and CRA 66 had significantly fewer diseased plants than eight other genotypes.

Inoculum density in the infested soil ranged from $1.6 \times 10^{2}$ to $1.7 \times 10^{3} \mathrm{cfu} / \mathrm{g}$ soil. Disease incidence ranged from 0 in Hawaii 7997 to $92 \%$ in XPH 5677, using the infested soil technique (Table 4). Differences in resistance were significant at $P<0.10$ (Table 2). As in the stem-puncture technique, Hawaii 7997, Hawaii 7998, and CRA 66 had the lowest disease incidence.

\section{Discussion}

The $P$. solanacearum strains were characterized to assess the potential strain variability within the Quincy production region and to draw comparisons to strains from other hosts or regions throughout the world. The race 1, biovar 1 designation is typical of P. solanacearum strains in the southeastern United States (Hayward, 1991; Velupillai and Stall, 1984). However, these characterizations alone do not indicate the potential variability among strains. For example, McLaughlin and Sequeira (1989) found that large biochemical and pathogenic differences existed among strains of $P$. solanacearum isolated from a single field in Hastings, Fla. In this study, comparing bacterial fatty acid profiles of a collection of strains from worldwide locations comprising three different races and biovars provided corroborative evidence of diversity among the Quincy strains.

Without a clear understanding of variability in virulence to tomato within a production region, breeders will be unsure of the stability of their resistant cultivars and the adaptability of resistant cultivars developed in other geographic regions. Successful screening will depend on including strains representative of the population found in commercial fields. The stem-puncture technique was used because it helps evaluate many $P$. solanacearum strainsmore than would be possible in evaluations conducted in naturally infested soil. Other common resistance screening techniques for bacterial wilt that permit the evaluation of many bacterial strains include the root-injury, root-dip, and clipping techniques (McCarter, 1973; Winstead and Kelman, 1952). In this study, the stem-puncture technique demonstrated that no significantly different responses occurred between strain and genotype. In addition, the Quincy strains were more virulent than the North Carolina strain. Thus, we would expect the resistance of genotypes Hawaii 7997, Hawaii 7998, and CRA 66 to be stable in this region.

In the previously mentioned screening techniques, the plant

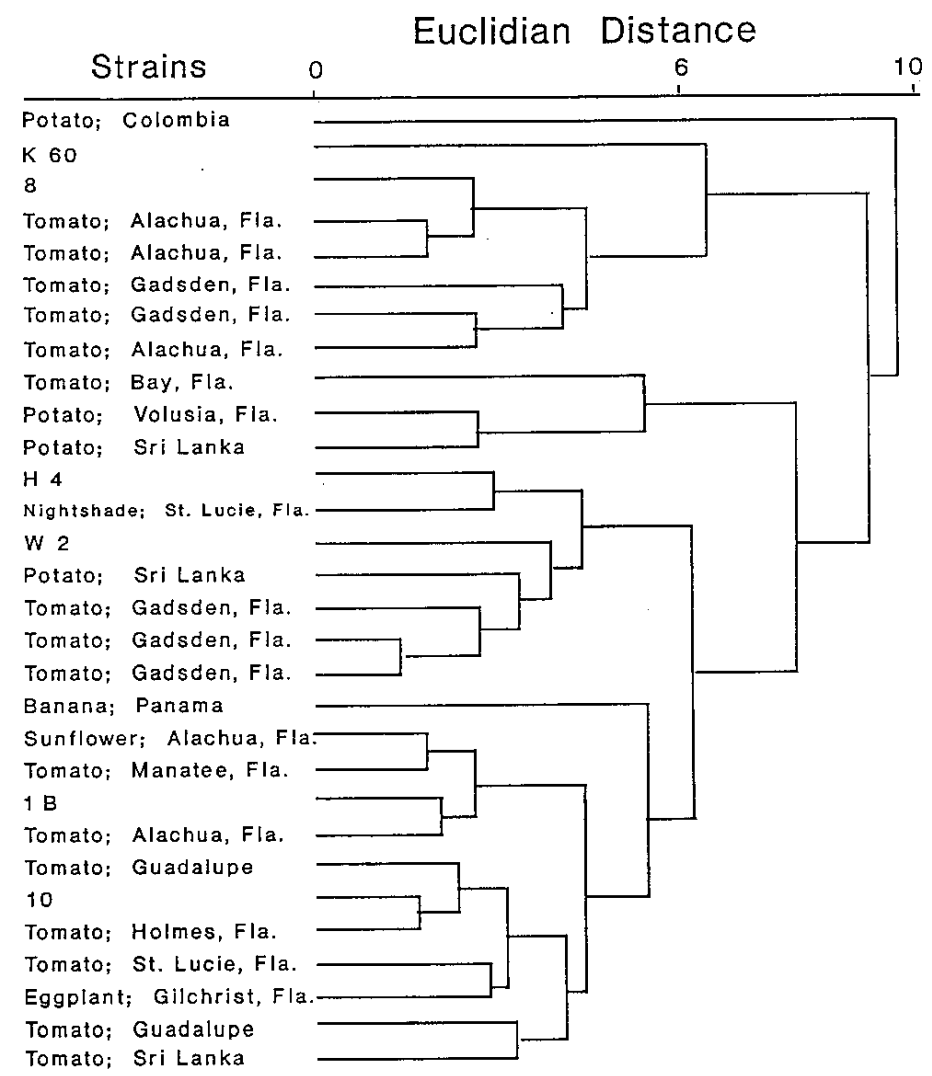

Fig. 1. Dendrogram derived from cluster analysis of fatty acids from 30 strains of Pseudomonas solanacearum. Strains are designated according to the plant host and county, state, or country from which they were isolated. Accession numbers are available from the authors. Strains H4, K60, W2, 1B, 8, and 10 were used in evaluating resistance to bacterial wilt. Strains within a Euclidian distance of ten are likely to be the same species, while strains that link within six units are likely to be the same subspecies or biotype.

Table 2. Analysis of variance (ANOVA) for data (transformed) from both resistance screening techniques.

\begin{tabular}{lccc}
\hline \hline Source & $\mathrm{df}$ & \multicolumn{1}{c}{ Mean square } & $P>\mathrm{F}$ \\
\hline \multirow{4}{*}{ Strain } & \multicolumn{1}{c}{ Stem-puncture } & technique & \\
Genotype & 5 & 4.41 & $<0.01$ \\
& 18 & 0.43 & $<0.01$ \\
Strain $\times$ genotype & 90 & 0.14 & 0.38 \\
& Infested-soil technique & \\
Replication & 2 & 0.17 & 0.52 \\
Genotype & 18 & 0.44 & 0.08 \\
\hline
\end{tabular}

Table 3. Pathogenic aggressiveness of six strains of Pseudomonas solanacearum.

\begin{tabular}{lc}
\hline \hline Strain & Disease incidence \\
\hline 10 & $94 \% \mathrm{a}^{\mathrm{x}}$ \\
W2 & $91 \% \mathrm{a}$ \\
8 & $89 \% \mathrm{a}$ \\
1B & $89 \% \mathrm{a}$ \\
H4 & $88 \% \mathrm{a}$ \\
K60 & $30 \% \mathrm{~b}$
\end{tabular}

${ }^{\mathrm{z}}$ Mean incidence of disease on 19 tomato genotypes and one tomatillo genotype inoculated using the stem-puncture technique.

${ }^{y}$ Weighted mean derived from transformed data.

${ }^{\mathrm{x}}$ Mean separation $(P \leq 0.05)$ by LSD. 
Table 4. Susceptibility of 19 tomato genotypes and one tomatillo genotype using the stem puncture and infested soil inoculation techniques.

\begin{tabular}{|c|c|c|}
\hline \multirow[b]{2}{*}{ Genotype } & \multicolumn{2}{|c|}{ Disease incidence $^{\mathrm{z}}$} \\
\hline & Stem puncture & Infested soil \\
\hline XPH5675 & $98 \% a^{y}$ & $92 \% \mathrm{a}$ \\
\hline XPH 5677 & $98 \%$ a & $47 \%$ a-d \\
\hline Island Red & $94 \% \mathrm{ab}$ & $23 \%$ a-d \\
\hline FMX 192 & $93 \% \mathrm{a}-\mathrm{c}$ & $67 \% \mathrm{a}-\mathrm{c}$ \\
\hline Venus & $92 \%$ a-d & $91 \%$ a \\
\hline Tomatillo & $91 \%$ a-d & $73 \%$ ab \\
\hline GA 219 & $87 \%$ a-e & $23 \% \mathrm{a}-\mathrm{d}$ \\
\hline GA 1405 & $85 \%$ a-e & $73 \% \mathrm{ab}$ \\
\hline IHR 66 & $83 \%$ b-f & $42 \%$ a-d \\
\hline Caraibo & $81 \%$ b-f & $75 \% \mathrm{ab}$ \\
\hline 84 BWR & $80 \%$ b-f & $78 \%$ ab \\
\hline CL 5915-93 & $79 \%$ b-f & $62 \%$ abc \\
\hline GA 1095 & $78 \% \mathrm{c}-\mathrm{f}$ & $45 \%$ a-d \\
\hline CL 5915-153 & $78 \% \mathrm{c}-\mathrm{f}$ & $84 \%$ a \\
\hline Capitan & $76 \% \mathrm{~d}-\mathrm{f}$ & $91 \% \mathrm{a}$ \\
\hline GA 1565 & $75 \%$ d-f & $51 \%$ a $-d$ \\
\hline PI 126408 & $69 \%$ ef & $23 \% \mathrm{a}-\mathrm{d}$ \\
\hline Hawaii 7997 & $67 \% \mathrm{f}$ & $0 \mathrm{~d}$ \\
\hline CRA 66 & $65 \% \mathrm{f}$ & $7 \% \mathrm{~b}-\mathrm{d}$ \\
\hline Hawaii 7998 & $63 \% \mathrm{f}$ & $2 \% \mathrm{~cd}$ \\
\hline
\end{tabular}

${ }^{\mathrm{Z}}$ Disease incidence expressed as a percentage of the disease incidence on the susceptible cultivars Sunny and Bonny Best. Disease incidence for the stem-puncture technique is a mean of the six strains used in this study.

yWeighted mean derived from transformed data.

${ }^{x}$ Mean separation $(P \leq 0.05)$ by LSD.

must respond to the presence of $P$. solanacearum after some type of stress has been applied. The response of healthy plants to a bacterial challenge is not considered. The high concentrations of the bacterial suspension used in these techniques $\left(10^{7}\right.$ to $10^{9} \mathrm{cfu} /$ $\mathrm{ml}$ ) are not representative of soil populations encountered in the fields (Granada and Sequeira, 1983; Hara and Ono, 1984; Khan et al., 1988). Such high concentrations may further overwhelm the already weakened defense mechanisms of the plant. Therefore, these inoculation techniques, when used as a screening method, do not reflect the level of resistance that may be expressed under field conditions.

Breeding programs in Florida have traditionally relied on field trials to differentiate resistance levels (Locascio et al., 1988; Sonoda and Augustine, 1978). Variable inoculum densities and uncontrolled environmental conditions may severely affect the outcome of field trials (Mew and Ho, 1977; Sonoda, 1978) and lead to variable results. The infested-soil technique was used because it permits the assessment of field resistance by allowing the infection process to take place under natural conditions with realistic doses of naturally produced inoculum. By conducting the technique under controlled conditions, the influence of temperature or moisture stress on disease is minimized. In this study, the high probability value associated with replication (Table 2 ) is a good indication that greenhouse conditions did not significantly affect results between treatments.

By combining several resistance screening techniques with the analysis of bacterial fatty acid profiles, a standardized method for quantifying diversity of $P$. solanacearum strains and differentiating levels of field resistance was obtained. From this, we conclude that, although $P$. solanacearum strains in the Quincy production region of northern Florida are biochemically diverse, based on fatty acid profiles, there is no significant specific interaction between strains and the 20 sources of resistance evaluated. Furthermore, the genotypes CRA 66, Hawaii 7998, and especially Hawaii 7997, seem to have a high level of field resistance to bacterial wilt. These observations agree with those by Sonoda et al. (1979) for the southeastern Florida tomato production area, but differ from those of Scott et al. (1993) for the southwestern Florida tomato production area, where $\mathrm{H} 7998$ tended to be more susceptible.

\section{Literature Cited}

Anais, F. 1986. Utilisation de la resistance varietale dans la lutte contre le fletrissement bacterien de la tomate Pseudomonas solanacearum E.F. Smith. Bul. Tech. Info. 409/411:449-452.

Buddenhagen, I.W., L. Sequeira, and A Kelman. 1962. Designation of races in Pseudomonas solanacearum. Phytopathology 53:726. (Abstr.)

Chellemi, D.O., D.J. Mitchell, and A.W. Barkdol. 1992. Effect of composted organic amendments on the incidence of bacterial wilt of tomato. Proc. Florida Hort. Soc. 105:364-366.

Enfinger, J.M., S.M. McCarter, and C.A. Jaworski. 1979. Evaluation of chemicals and application methods for control of bacterial wilt of tomato transplants. Phytopathology 69:637-640.

Granada, G.A. and L. Sequeira. 1983. Survival of Pseudomonas solanacearum in soil, rhizosphere, and plant roots. Can. J. Microbiol. 29:433440.

Hara, H. and K. Ono. 1984. Ecological studies on the bacterial wilt of tobacco, caused by Pseudomonas solanacearum E.F. Smith. Bul. Okayama Tobacco Expt. Sta. 43:31-40.

Hayward, A.C. 1964. Characteristics of Pseudomonas solanacearum. J. Applied Bacterial 27:265-277.

Hayward, A.C. 1991. Biology and epidemiology of bacterial wilt caused by Pseudomonas solanacearum. Annu. Rev. Phytopathol. 29:65-87.

Henderson, W.R. and S.F. Jenkins, Jr. 1972. Venus and Saturn. North Carolina Agr. Expt. Sta. Bul. 444.

Jaworski, C.A. and D.J. Morton. 1964. An epiphytotic of Pseudomonas solanacearum in tomatoes on newly-cleared Klej sand in relation to potassium, calcium, and magnesium levels. Plant Dis. Rpt. 48:88-89.

Jaworski, C.A., Phatak, S.C. Phatek, S.R. Ghate, R.D. Gitaitis, and M.P. Widrlechner. 1987. GA 1565-2-4BWT, GA 219-1-2 BWT, GA 1095-1-4 BWT, and GA 1405-1-2 BWT bacterial-tolerant tomato. HortScience 22:324-325.

Kelman A. and L.H. Person. 1961. Strains of Pseudomonas solanacearum differing in pathogenicity to tobacco and peanut. Phytopathology 51:158 161.

Khan, A.N.A., K.S. Shetty, and R.B. Patil. 1988. Multiplication of Pseudomonas solanacearum in rhizosphere and root tissue of susceptible and resistant varieties of Solanum melongena. J. Phytopathol. 121:313-317.

Krausz, J.P. and H.D. Thurston. 1975. Breakdown of resistance to Pseudomonas solanacearum in tomato. Phytopathology 65:1272-1273.

Locascio, S.J., R.E. Stall, and W.M Stall. 1988. Bacterial wilt expression in tomato as influenced by cultivar and lime. Proc. Florida State Hort. Soc. 101:356-358.

McCarter, S.M. 1973. A procedure for infesting field soils with Pseudomonas solanacearum. Phytopathology 66:799-800.

McLaughlin, R.J. and L. Sequeira, 1989. Phenotypic diversity in strains of Pseudomonas solanacearum isolated from a single potato field in northeastern Florida. Plant Dis. 73:960-964.

Mew, T.W. and W.C. Ho. 1977. Effect of soil temperature on resistance of tomato cultivars to bacterial wilt. Phytopathology 67:909-911.

Miller, L.T. 1982. Single derivation method for routine analysis of bacterial whole-cell fatty acid methyl esters, including hydroxy acids. J. Clinical Microbiol. 16:584-586.

Prior, P., H. Steva, and P. Cadet. 1990. Aggressiveness of strains of Pseudomonas solanacearum from the French West Indies (Martinique and Guadeloupe) on tomato. Plant Dis. 74:962-965.

Rolfs, P.H. 1898. Diseases of tomato. Florida Agr. Expt. Sta. Bul. 47:128:136.

SAS Institute. 1988. SAS/STAT user's guide. ed. 6.03. SAS Institute, 
Cary, N.C.

Sasser, M.J. 1990a. Identification of bacteria by gas chromatography of cellular fatty acids. MIDI, Newark, Del. Tech. Note 101.

Sasser. M.J. 1990b. "Tracking” a strain using the Microbial Identification System. MIDI, Newark, Del. Tech. Note 102.

Scott, J.W., G.C. Somodi, and J.B. Jones. 1993. Testing tomato genotypes and breeding for resistance to bacterial wilt in Florida. Proc. Intl. Bacterial Wilt Symp., Kaoshiung, Taiwan. (In press.)

Sonoda, R.M. 1978. Effect of differences in tolerance of tomato to Pseudomonas solanacearum and time of planting on incidence of bacterial wilt. Plant Dis. Rpt. 62:1059-1062.
Sonoda, R.M. and J.J. Augustine. 1978. Reaction of bacterial wilt-resistant tomato lines to Pseudomonas solanacearum in Florida. Plant Dis. Rpt. 62:464-466.

Sonoda, R.M., J.J. Augustine, and R.B. Volin. 1979. Bacterial wilt of tomato in Florida: History, status, and sources of resistance. Proc. Florida State Hort. Soc. 92:100-102.

Velupillai, M. and R.E. Stall. 1984. Variation of strains of Pseudomonas solanacearum from Florida. Proc. Florida State Hort. Soc. 97:209-213.

Winstead, N.N. and A. Kelman. 1952. Inoculation techniques for evaluating resistance to Pseudomonas solanacearum. Phytopathology 42:628634. 